\title{
Robinson Crusoe and the Earthy Ground
}

The island on which Robinson Crusoe lives for twenty-seven years is strewn with things - caps, shoes, pots, coins, sheep-skins, bones, and guns — and critics have had much to say about them. In this essay, however, I cast an eye down to the earth that lies beneath these things. The ground in Robinson Crusoe has tended to pass below comment, regarded as an empty and abstract backdrop against which Crusoe and his things emerge in all their individuality and particularity. In Virginia Woolf's account of the episode in which Crusoe fashions an earthenware pot, for example, the earth from which the pot is made is made to disappear into the nothingness that surrounds it after its completion. The lonely pot is, for Woolf, an emblem of the descriptive austerity of a book in which "There are no sunsets and no sunrises; there is no solitude and no soul. There is, on the contrary, staring us full in the face nothing but a large earthenware pot."1 Cynthia Wall extends Woolf's judgement of Robinson Crusoe outward to the early novel as a whole, which she contends does not present "fully visualized spaces" and instead "describes things." A similar sense of the island as a functional void underlies Wolfram Schmidgen's argument that the first book of Robinson Crusoe presents the island as "terra nullius," or legally unpossessed land. The island, for Schmidgen, is "a negative space, a boundless vacuum...in search of a possessive content," an abstract nothingness that only acquires particularity and form when Crusoe arrives to take possession of it. ${ }^{3}$ My own essay, however, questions the assumption that earthy expanses in the Crusoe trilogy are bare backdrops on which actors and objects are staged and claims to

\footnotetext{
${ }^{1}$ Virginia Woolf, "Robinson Crusoe," in The Common Reader, Second Series, ed. Andrew McNellie (London: Hogarth, 1986), 54.

${ }^{2}$ Cynthia Sundburg Wall, The Prose of Things: Transformations of Description in the Eighteenth Century (Chicago: The University of Chicago Press, 2006), 1.

${ }^{3}$ Wolfram Schmidgen, Eighteenth-Century Fiction and the Law of Property (Cambridge: Cambridge University Press, 2002), 44.
} 
ownership are advanced. The earth in the first book of Robinson Crusoe is far from a passive object of Crusoe's labors and possessive instincts. It threatens to bury him alive, frightens him with a footprint, and startles him by seeming to spontaneously produce shoots of barley and rice. Over the course of the three volumes of Robinson Crusoe as a whole, human beings are not presented as beings separate from the earth. Rather Crusoe and other human figures are frequently seen to merge with a vital earthiness that appears to be just as alive as they are. ${ }^{4}$ I would claim of the personhood in the Crusoe trilogy as a whole what Helen Thompson argues of personhood in the Journal of the Plague Year, that "Far from a bounded individual, Defoe's model for character is chemical medicine's pervious person." ${ }^{\prime 5}$ As Thompson argues, the hypothesis that the basic building blocks of matter were what Robert Boyle called "corpuscles," particles invisible to the eye but whose shape could be inferred through the manner in which they interacted with the human senses and with other conglomerations of corpuscles, helped inform Defoe's narratives of permeable human beings who both absorb elements of their environments and are absorbed by them. I will argue that it is by putting Crusoe in mutual interaction with a vital earth that the Crusoe books emerge most clearly as visions of empire, not by holding Crusoe superior to and separate from his environment. The trilogy as a whole foresees successors to Crusoe following his lead in reshaping the surface of the earth, a reshaping that the books present as an extension of the earth's own vital processes.

\footnotetext{
${ }^{4}$ Emmanuelle Peraldo makes a similar argument that the landscape in the first volume of Robinson Crusoe "is not merely a setting for his characters but fully integrated and continuous with them, in a single interconnected realm." Emmanuelle Peraldo, "Two broad shining eyes': Optic Impressions and Landscape in Robinson Crusoe," Digital Defoe: Studies in Defoe and his Contemporaries, 4 (2012), 18. My argument is focused more specifically on the continuity between earth and human beings and makes connections across the Crusoe trilogy as a whole.

${ }^{5}$ Helen Thompson, Empiricism, Corpuscles, and the Novel (Pennsylvania: The University of Pennsylvania Press, 2017), 113.
} 
The earth in the Crusoe trilogy is continually in motion: shaking, changing shape, generating life, and threatening death. Defoe's presentation of an active and animate earth in the Crusoe books is guided by new understandings of the earth in scientific and agricultural writings, which discovered new sources of vitality in the earth. In the Crusoe books, the earth acquires a conceptual vitality to match its material liveliness. Defoe fully exploits the polysemy of the word "earth" itself, a word that encompasses vertiginous shifts in scale and reference. The Oxford English Dictionary attests to the word's semantic range, which can signify the ground "as a surface on which human beings, animals, and things associated with them rest or move," "the soil as suitable for cultivation," and "a place for burying the dead." In its wider applications, the earth can mean "Dry land, as opposed to the sea or other body of water," "Land and sea as opposed to the sky," and the world itself, whether considered as a planet or as opposed to "heaven, hell, or some other place of future existence." of "earth" to refer to both the small patch of soil on which Crusoe sows his first seeds of corn as well as the planet as a whole allows the word to evoke a fluid kind of materiality that overflows the confines of a single discrete thing. To only discuss the island's arable soil would be to miss how Defoe himself exploits the tendency of the word "earth" to move between human and world scales as well as between material and spiritual registers. This semantic elasticity of the word helps the trilogy to present the labors of one man on a small island off Trinidad as a synecdoche for the planting and improvement of colonies on a planetary scale, as well as allowing the transformation of island's soil to act as the counterpart to, and necessary condition of, the transformation of Crusoe's soul.

The earth thus helps define the relation between the material world on which Crusoe walks and works and the spiritual one that he learns to discern behind it. ${ }^{7}$ In exploring how

\footnotetext{
${ }^{6}$ OED Online, s.v., "earth, n.,", www.oed.com/view/Entry/59023. (accessed 10 July 2017). ${ }^{7}$ The earth is an area in which the "spiritual" and "material" dimensions of the Crusoe books share a common border. The earth, like the air in Jayne Elizabeth Lewis's reading of the
} 
Crusoe's environment mediates between the material and the spiritual, my approach complements Jayne Elizabeth Lewis's reading of the air in the first volume of Robinson Crusoe, an air that is at once an actual atmosphere, an index of the invisible world of spirits and apparitions, and a metaphor for fictionality itself. ${ }^{8}$ In this essay I will expand on Lewis's passing remark that two processes of conversion play out over the course of the novel, namely “Crusoe's spiritual (or figural) conversion and his agricultural (or literal) conversion of virgin soil into crop-bearing field." $"$ My essay seeks to show, however, rather than envisaging the conversion of the soul as standing in the relation of tenor to vehicle to the conversion of the soil, the Crusoe books present the material and spiritual varieties of conversion as components of a single process. The convulsions of the earth mediate and make possible Crusoe's spiritual conversion, which is subsequently displayed outwardly in the physical and spiritual labors that he performs upon the earth.

Defoe does not present people as creatures wholly sundered from the earth they walk upon. To the contrary, images of the ground, shocking, shaking, or swallowing up human beings crop up across the Crusoe trilogy and in writings by Defoe as disparate as A Journal of the Plague Year (1722) and A Tour thro' The Whole Island of Great Britain (1724-26). These visions of humans being incorporated into the processes of an active earth resonate

novel, cited below, helps bring together the "material" and "spiritual" aspects of the Crusoe trilogy, which have produced largely separate and apparently mutually exclusive lines of interpretation. For the split between the "material" and "spiritual" readings of Robinson Crusoe and another attempt to reconcile them, see Wolfram Schmidgen, "The Metaphysics of Robinson Crusoe," ELH 83 (2016), 101-26.

${ }^{8}$ Jayne Elizabeth Lewis, Air's Appearance: Literary Atmosphere and British Fiction, 16601794 (Chicago: The University of Chicago Press, 2012), chpt. 4.

9 “The Atmospheres of Robinson Crusoe," 49. Rajani Sudan draws attention to how earthy materials were fashioned into the material supports and commodities of Britain's new commercial empire such as mortar and chinaware and in her brief analysis of Robinson Crusoe, she observes, "There is, perhaps, no more gratifying use of mud in the eighteenthcentury novel than in Daniel Defoe's first volume of Robinson Crusoe." The Alchemy of Empire: Abject Materials and the Technologies of Colonialism (New York: Fordham University Press, 2016), 12. My own essay follows up on Sudan's suggestion that much more remains to be said on the subject of earth in Robinson Crusoe. 
with the writings of contemporary ecocritical and new materialist thinkers. Timothy Morton in The Ecological Thought, for example, wishes to do away with the very idea of "nature" and insist instead on the "vast, sprawling mesh of interconnection without a definite center or edge" in which living and non-living things are entangled. Similarly, Jane Bennet in Vibrant Matter challenges the assumption that agency is the exclusive property of human beings, instead regarding agency as distributed over a network that includes both living and unliving things. ${ }^{10}$ I understand my own essay, however, not as an attempt to use these rethinkings of the relationship between human beings and the environment to read the Crusoe books against their own grain. My essay seeks instead to demonstrate how thoroughly the Crusoe trilogy muddies the distinction between the matter and motions of Crusoe's body and those of the earth. My starting point is not a work of contemporary ecocriticism but a very old story about the relationship between human beings and the earth on which they live.

\section{The Earth and the Human}

According to the Bible, the first human being was fashioned directly out of the ground. In the King James Bible, God is said to have molded Adam from the "dust of the ground" and breathed life into his nostrils (Genesis 2.7). After Adam has followed Eve in disobeying God by eating from the Tree of Knowledge, God tells Adam that "cursed is the ground for thy sake; in toil shalt thou eat of it all the days of thy life...In the sweat of thy face shalt thou eat bread, till thou return unto the ground; for out of it wast thou taken: for dust thou art, and unto dust shalt thou return" (Genesis 3:17). In the original Hebrew, God's fateful words play on the closeness of Adam's name אדם ("humankind") to the Hebrew word

\footnotetext{
${ }^{10}$ Timothy Morton, The Ecological Thought (Cambridge, M.A.: Harvard University Press, 2010), 8; Jane Bennett, Vibrant Matter: A Political Ecology of Things (Durham, N.C.: Duke University Press, 2010).
} 
אדמה ("ground"). ${ }^{11}$ Genesis's revelation of the earthy nature of human beings is referenced in the English burial service ("earth to earth, ashes to ashes, dust to dust") and had long been the source of the conventional homily that all human beings, no matter their wealth or fame on earth, share a common bodily fate in the ground. ${ }^{12}$ Despite the familiarity of the idea of human beings as earth-born and earth-bound creatures, to perceive oneself and other human beings as literally earth still required an effort of the imagination. As John Bunyan remarks in his commentary on Genesis 3.17 in his Exposition on the First Ten Chapters of Genesis (1692), "It is hard for us to believe it, though we daily see it is the way even of all the earth, to return hither again."13 Human beings are so loath to see themselves as mere clumps of earth that they discount the evidence of their own senses. To use the language of Russian Formalism, it is only defamiliarizing descriptions of the earth that that succeed in making, in Viktor Shklovsky's words "the stone stony" and the earth earthy. ${ }^{14}$ Over the course of his writings across multiple genres, Defoe often seems consciously concerned to overcome his readers' resistance to seeing themselves as things made of earth and destined to return to it and to disclose the vitality of the earth as well as the earthiness of living things.

\footnotetext{
${ }^{11}$ On the link between אדמה and wדם, which share the same root in Hebrew, see, for example, Mari Jørstad, "The Ground That Opened its Mouth: The Ground's Response to Human Violence in Genesis 4," Journal of Biblical Literature 135 (2016), 706.

12 The quote is from the 1662 Burial of the Dead in the The Book of Common Prayer, ed. Brian Cummings (Oxford: Oxford University Press, 2011), 455. For one example of the memento mori tradition drawing on the sentence God that passes on Adam to labour on the earth and return to it see, for example, the various versions of the medieval poem known as "Erthe upon Erthe," which were still current in the seventeenth and early eighteenth century in Erthe upon Erthe, ed. Hilda M.R. Murray (London: Oxford University Press, 1911). ${ }^{13}$ John Bunyan, Miscellaneous Works, ed. W.R Owens (Oxford: Clarendon Press, 1994), 151.

${ }^{14}$ Victor Shklovsky, “Art as Technique," in Russian Formalist Criticism: Four Essays, trans. Lee T. Lemon and Marion J. Reis (Lincoln, N.E.: University of Nebraska Press, 1965), 12. On the defamiliarization of the ordinary in the first book of Robinson Crusoe see Sarah Tindall Kareem, Eighteenth-Century Fiction and the Reinvention of Wonder (Oxford: Oxford University Press, 2014), chpt. 2.
} 
Defoe makes the kinship of human beings with the earth shockingly literal, for example, in A Journal of the Plague Year, in which he has H.F. relate rumors of how many plague victims did not require burial in the pits that had been dug to hold them. Instead, plague-stricken people,

would run to those Pits wrapt in Blankets, or Rugs, and throw themselves in, and as they said, bury themselves: I cannot say, that the officers suffered any willingly in a great Pit in Finsbury, in the Parish of Cripplegate, it lying open then to the Fields; for it was not then wall'd about, came and threw themselves in, and expired there, before they threw any Earth upon them; and that when they came to bury others, and found them there, they were quite dead, tho' not cold. ${ }^{15}$

Sophie Gee observes that this account performs on the level of grammar what it describes on the level of content: "the syntax of the passage is distorted; it becomes increasingly difficult to separate the living and the dead, as pronouns referring to the officers collapse into those referring to the dying."16 The syntactical merging of the buriers and the buried seems motivated in part by the passage's account of the plague victims, living and dead, falling together into an undifferentiated earth. ${ }^{17}$ In the passage from the Journal of the Plague Year, people are drawn as if by an unseen force back into the earth from which they are made,

\footnotetext{
${ }^{15}$ Daniel Defoe, A Journal of the Plague Year, ed. John Mullan (London: Pickering \& Chatto, 2009), 70.

${ }^{16}$ Sophie Gee, Making Waste: Leftovers and the Eighteenth-Century Imagination (Princeton: Princeton University Press, 2010), 116.

${ }^{17}$ David Hollingshead in a recent essay inspired by Giorgio Agamben's work on the relationship between sovereignty and the state of exception also quotes this passage from $A$ Journal of the Plague Year and Gee's discussion of it in Making Waste, but provides a different account of its significance, arguing that "H.F.'s indefinite pronouns remind us that human agency and intentionality are some of the conceptual categories most thoroughly called into question when individuals and collectives converge as abandoned life in the state of exception." My point is that the passage stages an even more radical convergence between human beings and the ground from which they spring. See "Daniel Defoe and Abandoned Life," Studies in the Novel 49 (2017), 14.
} 
forcing readers to regard themselves as temporary forms taken by a ceaselessly moving earth. $^{18}$

The kinship of Crusoe with the earth is bound up with his status as a new Adam, sharing his allotted fate to labor on the ground and eventually to return to it. In the first book of Robinson Crusoe, Crusoe explicitly compares himself to the earth-made Adam when he comments on how, in the absence of any division of labor, he must perform all the "strange multitude of little Things" involved in the production of just one loaf of bread. He then evokes Genesis 3.17, commenting that "It might be truly said, that now I work'd for my Bread." ${ }^{19}$ Crusoe's first years on the island are, as Ann Van Sant observes, "marked by labor and pain," recapitulating Adam's postlapsarian toils on a cursed earth that requires human labor before it can yield sustenance to human beings. ${ }^{20}$ Although Crusoe refers only to the first part of the fate allotted to Adam, of eating bread in the sweat of his face, the second part concerning his origin in and destiny to return to the ground is intimated constantly in the first volume of Robinson Crusoe, most obviously when he is nearly buried alive in the earthy cave in which he makes his first home on the island.

The suggestion that human beings may not be distinct from the earth on which they work is also an implication of the Lockean theory of property in the Two Treatises of Government (1689) that underpins Crusoe's claims to ownership over the island. In the second Treatise, Locke argues human beings acquire property by mixing their labor with the

\footnotetext{
${ }^{18}$ For a reading of how A Journal of the Plague Year envisages human beings as, like the solids and liquids investigated by seventeenth-century corpuscularians, thoroughly penetrable by disease-carrying “corpuscles," see Helen Thompson, Fictional Matter, chpt. 3.

${ }^{19}$ Daniel Defoe, The Life and Strange Surprising Adventures of Robinson Crusoe, ed. W.R. Owens (London: Pickering \& Chatto, 2009), 144. All subsequent references to the Strange Surprising Adventures are to this edition, designated as $R C$ in the text.

${ }^{20}$ On Crusoe as a second Adam see, for example, J. Paul Hunter, The Reluctant Pilgrim: Defoe's Emblematic Method and Quest for Form in Robinson Crusoe (Baltimore: The Johns Hopkins University Press, 1966), 133 and Stephen H. Gregg, Defoe's Writings and Manliness: Contrary Men (London: Ashgate, 2009), chpt. 3.
} 
earth and its fruits. "Whatsoever," Locke writes, "he removes out of the state that Nature hath provided and left it in, he hath mixed his labour with it, and joined to it something that is his own, and thereby makes it his property." Human labor is seen to produce property in land and its resources just as surely as it alters them from their natural state: "the grass my horse has bit; the turfs my servant has cut; and the ore I have digged in any place, where I have a right to them in common with others, become my property, without the assignation or consent of any body. The labour that was mine, removing them out of that common state they were in, hath fixed my property in them." ${ }^{21}$ But the Crusoe books also develop the barely concealed implication in Locke's own account of property that human beings can equally well be seen as processors of earth as possessors of it, something that Locke seems to be just on the point of articulating when he runs through the various possibilities for pinpointing exactly when a man gains property in the edible things he takes from the common:

He that is nourished by the acorns he picked up under an oak, or the apples he gathered from the trees, has certainly appropriated them to himself. Nobody can deny but the nourishment is his. I ask, then, when did they begin to be his? when he digested? or when he ate? or when he boiled? or when he brought them home? or when he picked them up? And it is plain, if the first gathering made them not his, nothing else could. ${ }^{22}$ Laurence Sterne's scatological parody of this passage in Tristram Shandy (1759-67), using the metaphor of the apple to ask when Walter Shandy's could be said to have come into possession of one of his opinions - "how did it begin to be his? was it when he set his heart upon it? or when he gathered it? or when he chewed it? or when he roasted it? or when he peeled it? or when he brought it home? Or when he digested? Or when he---------?”- simply draws out what is already latent in Locke: the awareness that human beings can be seen

\footnotetext{
${ }^{21}$ John Locke, Two Treatises of Government, ed. Peter Laslett (Cambridge: Cambridge University Press, 1960), 288.

${ }^{22}$ Ibid., 287-88.
} 
simply as conduits through which earth-made food passes into earth-bound excrement, before they themselves return to the earth from which they are made. ${ }^{23}$ To use Locke's own terms, the Crusoe books emphasize not just the fixing of human property in the earth and its resources but also the mixing of human labor with the earth, a mixing that inevitably accompanies human claims to property over the earth and its resources. ${ }^{24}$

Like Locke's acorn and apple gatherer, Crusoe is both the proud asserter of property rights and the earth's humble laborer and manurer. His double status as both possessor of the island and its prisoner corresponds to his contradictory self-descriptions as the island's king and captive. Crusoe oscillates between the same modesty and pride that Joanna Picciotto associates with seventeenth-century natural philosophers, whose self-comparison of themselves to Adam produced a sense of both humility and hubris: “Adam's digging is the proper expression of his own humble material origins - linking humilitas and humus - but it also declares his resemblance to the Creator: the material on which Adam works is the material from which God made him.." 25 Like Crusoe with his trials of sowing seeds of corn at different times in the year, seventeenth-century philosophers were drawn to experiment with

\footnotetext{
${ }^{23}$ Laurence Sterne, The Life and Opinions of Tristram Shandy, Gentleman in The Florida Edition of the Works of Laurence Sterne, ed. Melvyn and Joan New, 6 vols. (Gainesville: University Press of Florida, 1978), I:263.

${ }^{24}$ For the Lockean underpinnings of Crusoe's claims to property, see Schmidgen, EighteenthCentury Fiction and the Law of Property, chpt. 2. My essay unearths the way these claims to property through labor paradoxically confront Crusoe with the animate energies of the earth and the earthiness of his own body. Locke's understanding of property as stemming from a mixing of human labour with the earth anticipates Karl Marx's concept of labor as "a process between man and nature, a process by which man, through his own actions, mediates, regulates and controls the metabolism between himself and nature." See Capital Volume I, trans. Ben Fowkes (London: Penguin, 1990), 283. Both Locke and Marx sees human beings, however, as controlling this mixing or metabolism with the natural world. I argue, however, that Defoe explores the possibility that human beings might be less in control of this mixing or metabolism with nature than they might realise.

25 Joanna Picciotto, Labors of Innocence in Early Modern England (Cambridge, M.A.: Harvard University Press, 2006), 42.
} 
the earth itself, thus making the metaphor of the virtuoso as the delving Adam literal. ${ }^{26}$ One of these earth-delving natural philosophers was John Evelyn, a member of the Georgical Committee formed of members of the Royal Society devoted to advancing the art of agriculture. Evelyn and his peers discovered a liveliness and heterogeneity in the earth unsuspected by the ancients. Aristotle, for example, had conceived the earth in the Physics as, together with water, air, and fire, one of the four simple bodies, whose natural inclination is to fall downwards "to the centre," where it would come to rest once it could fall no further. ${ }^{27}$ Evelyn acknowledged received ideas of the earth as a usually inactive substance in $A$ Philosophical Discourse of Earth (1676), asking rhetorically "what is there in Nature so sluggish and dull as Earth?"28 Yet he went on to write that the earth, "though the lowest, and most inferiour of them all, is yet so subservient, and necessary to Vegetation, as without it there could hardly be any such thing in Nature." ${ }^{29}$ Evelyn declines to define exactly what earth is as a substance "denudated and stripp'd of all Heterogeneity" or even to broach the question of whether the earth as a planet revolves around the sun or the sun around the earth. ${ }^{30}$ Rather, Evelyn elects to survey the variety of forms the earth as a substance can take, training his microscope on samples of clay and chalk, as well as the dung of horses, and pigeons. In Evelyn's and other natural philosophers' delvings into the nature of earthy matter helped imbue the earth with a heterogeneity and fecundity that belied its "sluggish and dull" reputation.

In the physics textbook Compendium Physicae (1687), which Defoe studied as a student at the dissenting Newington Green Academy, Defoe's teacher Charles Morton did see

\footnotetext{
${ }^{26}$ On Crusoe as an experimenter, see John Bender, Ends of Enlightenment (Palo Alto: Stanford University Press, 2012), chpt. 1.

${ }^{27}$ Aristotle, The Complete Works, ed. Jonathan Barnes (Princeton: Princeton University Press, 1984), I:486.

${ }^{28}$ John Evelyn, A Philosophical Discourse of Earth (London, 1676), 8.

${ }^{29}$ Ibid., 9.

${ }^{30}$ Ibid., 11.
} 
earth as a more lethargic substance than Evelyn did, explaining earth in corpuscularian terms as a substance whose observed qualities emerged from the small-scale shapes of the particles that made it up. Morton defined earth as "a Mass of Gross particles, of Irregular figures sticking togather, by their Quiet or absence of motion through unaptness thereunto." ${ }^{31}$ Yet Morton also noted in the same treatise that earthy matter was a substance capable of passing through many plants and animals via nature's cycles of growth and decay: "the Same particle of matter may pass under diverse forms in diverss bodyes, and never be destroyed or lost; as in a man, Earth, Grass, beasts, and man again... and So on through never so many mutations as you can Imagine." 32 Recapitulating Aristotle's theory of earthquakes in his Meteorology, Morton wrote that earthquakes were caused by steamy winds in the earth, which "Vehemently seek an outlet, and meeting with obstruction therein, they rush violently" in underground channels ("caverns") and cause the earth around these channels to shake. ${ }^{33}$ But Morton departed from Aristotle in seeing thunderbolts as made of earthy matter, explaining that they are composed of "three principle parts Sulphur, Niter, and Water, and Sometimes there are Earthy, Sandy and Minerall steams among them, the matter of which is ca'ld the thunder bolt." ${ }^{34}$ Despite Morton's definition of the earth as a mass of particles that resisted motion, the earth in Compendium Physicae as a whole emerges as a substance in motion,

${ }^{31}$ Charles Morton, Compendium Physicae, ed. Theodore Hornberger in Publications of the Colonial Society of Massachusetts, vol. 33. (Boston: Colonial Society of Massachusetts, 1940), 73. The version of the textbook printed in this edition was the one later used by Morton at Harvard University, but he was already teaching the material it contains in the 1670s when Defoe was a student at the academy. Defoe later remembered Morton's lectures in his 1704 More Short Ways with the Dissenters. On the Defoe-Morton connection see Ilse Vickers, Defoe and the New Sciences (Cambridge: Cambridge University Press, 1996), 39. For Robert Boyle's influence on how Morton conceived the fundamental nature of matter, see Thompson, Fictional Matter, 134.

32 Ibid., 12.

${ }^{33}$ Ibid., 98. For Aristotle's corresponding explanation of earthquakes sin the Meterology see The Complete Works, I:591-96.

${ }^{34}$ Ibid., 87, 85. 
whether it is shaking in earthquakes, shooting from the sky in thunderbolts, or circulating through plants, beasts, and human beings.

At the same time that natural philosophers were rethinking the nature of earth as a substance, other natural philosophers like Thomas Burnet were rethinking the nature of the earth as a planet. In the Theory of the Earth (Latin version 1680, English version 1684), Burnet set out to explain the uneven appearance of the earth's surface, with its mountain ranges, plains, continents, and seas, by way of the biblical story of the flood. He claimed that the antediluvian earth floated on an abyss of water, at which time its surface was perfectly smooth: "it had the beauty of Youth and blooming Nature, fresh and fruitful, and not a wrinkle, scar or fracture in all its body; no Rocks nor Mountains, no hollow Caves, nor gaping Chanels, but even and uniform all over." 35 However, during the course of the flood, the earth's surface fractured and fell into the watery abyss and the ensuing shattering of the surface created the fractured and fragmented condition of the postdiluvian earth. Defoe in A General History of Trade (1713) referred to Burnet's theory, summing up Burnet's view of postdiluvian earth as "a great Ruin, where the pieces hang as if broken off from one another, and look like a vast Mountain overwhelm'd by some Earthquake." 36 However, Defoe disagreed with Burnet that the earth's fall into the abyss was necessarily a turn for the worse, suggesting that even this "Confusion and appearing Dislocation" had "the greatest Beauty and Harmony imaginable in it" since the destruction of the primordial earth was what made navigation and trade possible. ${ }^{37}$

\footnotetext{
35 Thomas Burnet, The Theory of the Earth, 2 vols. (London, 1684), I:67. For more on early modern rethinkings of the nature of the earth in an age of expanding empire and commerce see Lydia Barnett, After the Flood: Imagining the Global Environment in Early Modern Europe (Baltimore: Johns Hopkins University Press, 2019).

${ }^{36}$ Daniel Defoe, A General History of Trade (London, July 1713), 32.

${ }^{37}$ Ibid., 33. John Richetti observes of this claim that it "is surely a heterodox theodicy, a very odd addition to natural theology, but Defoe is always an enthusiastic autodidact when it comes to his pet topic of trade." See The Life of Daniel Defoe: A Critical Biography (Chichester: Wiley-Blackwell, 2005), 153.
} 
A similar sense that progress follows from violent upheavals of the earth informs Defoe's Caledonia \& c.: A Poem in Honour of Scotland, and the Scots Nation (1706), written as part of the propaganda Defoe produced to support the union of Scotland with England. In the introduction to the poem, Defoe disingenuously disavowed any interest in promoting the impending union, instead offering his poem as a paean to the agricultural potential of an improved Scotland: "With or without an Union the Lands may be improved, the Tenants incouraged, the Fields inclosed, woods planted, the Moors and Wastes fed, and Scotland recovered from languishing Poverty." 38 In the poem itself, Defoe envisages the future improvement of Scotland as a violent rape of virgin land:

Natures a Virgin very Chast and coy,

To Court her's nonsence, if ye will enjoy,

She must be ravish't

When she's forc't she's free,

A perfect prostitute to industry... $(1250-55)^{39}$

The poem presents improvement as a matter of making a personified female nature sexually subject to a masculine human industry. Yet when Defoe set himself to narrating the sequence leading from labor on the earth to sustenance and profit, he came to dwell on those moments in which the earth, far from passively opening itself up to a penetrating human industry, appears instead to threaten to absorb those who labor on it.

${ }^{38}$ Daniel Defoe, Political and Economic Writings of Daniel Defoe: Volume 4: Union with Scotland, ed. D.W. Hayton (London: Pickering \& Chatto, 2000), 216. References to Caledonia are to this edition, given by line number in the text.

${ }^{39}$ Maximillian E. Novak quotes these verses in a short discussion of Defoe's agricultural writings. See Daniel Defoe: Master of Fictions His Life and Ideas (Oxford: Oxford University Press, 2001), 306-7. Novak also quotes a Scottish contemporary of Defoe's, John Clerk of Penicuik, who attested to his being "very knowing" on the subject of agriculture (309). 
A striking example of this appears in Defoe's Tour thro' the Whole Island of Great Britain, whose Preface presents Britain as a land undergoing rapid change. The changing nature of Defoe's subject prompts the disclaimer that the Tour will attempt to capture the island as it appears in the fast-receding present: "The Situation of Things is given not as they have been, but as they are, the Improvements in the Soil, the Product of the Earth, the Labour of the Poor, the Improvement in Manufactures, in Merchandizes, in Navigation, all respects the present Time, not the Time past." ${ }^{\prime 0}$ The earth is the ground on which Britain's prosperity rests, a substance that is converted into material wealth through the act of labor. But in the section of the Tour dealing with Defoe's travels among the Derbyshire lead mines, Defoe tells the story of an encounter with an "subterranean Creature" who seems to merge with the ground he labors in. Defoe and his party travel up to a mountain popularly said to be the giant's burial ground, where they meet a woman living in a cave under the tombstone that marks where the giant is supposedly interred. Although the company see no evidence of any giant, they are treated to almost as fantastic a sight. The woman leads the party to a valley where narrow grooves are cut into the earth's surface in order to allow the lead miners to descend into their depths. As they gaze on one groove they are startled to see "Hand, and then an Arm, and quickly after an Head" emerging from one of the grooves:

Immediately we rode closer up to the Place, where we saw the poor Wretch working and heaving himself up gradually, as we thought, with Difficulty; but then he shewed us that it was by setting his Feet and Elbows upon Pieces of Wood fixt cross the Angles of the Groove like a Ladder, we found the Difficulty was not much, and that if the Groove had been larger, he could not go up and down with so much Ease or Safety. ${ }^{41}$

\footnotetext{
${ }^{40}$ Daniel Defoe, Writings on Travel, Discovery and History, ed. W. R. Owens, Philip Nicholas Furbank, and John McVeagh (London: Pickering \& Chatto, 2006), I:48.

${ }^{41}$ Ibid., III: 36.
} 
This passage reverses A Journal of the Plague Year's account of human beings dying and merging with the earth, instead presenting the lead miner as if he were a corpse emerging from the ground. He is described as being "lean as a Skeleton, pale as a Corpse, his Hair and Beard a deep black; what little Flesh he had, was lank, and, we thought, something of the Colour of the Lead itself." The boundary between the miner and the earth in which he works is a permeable one: just as the miner mixes his labor with the lead the lead, in turn, mixes itself with the miner, who takes on the metal's qualities. The earthy ground in the Tour provides the basis for national wealth not only through agriculture, then, but also through the valuable minerals and metals to be found within it. Later in the Tour, in reporting a rumor that the county of Caithness in Scotland holds seams of lead and other valuable metals, Defoe reflects that:

Should a Time come, when these hidden Treasures of the Earth shall be discovered and improved, this Part of Scotland would be no longer esteemed poor; for such a Production would change the Face of Things, bring Wealth and Commerce to it, fill the Harbours with Ships, the Towns with People, and, by consuming the Provisions, occasion the Soil to be cultivated, the Fish cured, the Cattle consumed at Home, and thereby diffuse Prosperity all around them.

The Derbyshire lead miner suggests, however, that if this transformation of Caithness from poverty to prosperity is to happen, then many more miners like him would need to be sent into the earth, where they would presumably also become permeated with the objects of their labors. Because Crusoe in the Strange Surprizing Adventures spends much of the book as both laborer and the consumer of the fruits of his labor there is no possibility for him of escaping being mixed with the earth on which he works. In the remaining part of this essay, I will argue that Defoe pursues the radical implications of the accounts of the human relationship with the earth that he found in Genesis, in Locke's theory of property, and in the 
scientific writings on the earth by Morton, Burnet, and others. Defoe's earthy imagination, I argue, tends to position human beings and the earth as interpenetrating and reciprocally interacting with one another, rather than holding human beings as separate to and superior to the earth. I begin with one of the books' limit cases, in which Crusoe is seen on the point of being absorbed wholly into a metamorphosized sea of earth.

\section{Crusoe and the Earth}

Tossed and turned about by the wind and the waves and searching desperately for a safe harbor, Crusoe and the sailors with whom he is travelling sight land while they are trapped in a storm. But they are unable to make out "What the Shore was, whether Rock or Sand, whether Steep or Shoal" and so cannot determine whether or not the land will offer a safe landfall. Crusoe and the rest of sailors hope that the island might present some "Bay or Gulph, or the Mouth of some River" in which they might shelter. But the island refuses to present any such landing, since "nothing of this appeared; but as we made nearer and nearer the Shore, the Land look'd more frightful than the Sea." After he is thrown into the ocean by a "raging Wave, Mountain-like," the struggling Crusoe experiences the sea as a moving mass of earth that threatens to overwhelm him with its power: "I saw the Sea come after me as high as a great Hill, and as furious as an Enemy which I had no Means or Strength to contend with" $(R C, 89)$. The second wave that crashes down on Crusoe "buried me at once 20 or 30 Foot deep in its own Body" and the fourth "landed me, or rather dash'd me against a Piece of a Rock" $(R C, 90)$. The waves that threaten to bury Crusoe alive or break his body are not actual walls of earth. Yet they anticipate the restless energies that the actual earth will assume later in the book. Crusoe is helpless to resist the force of these earth-like waves that foreshadow the earthquakes to come. They refuse to allow Crusoe a secure footing on the ground, allowing Crusoe only brief moments of respite when, following their retreat, he can 
run towards the shore, before they return and sweep him off his feet once again. And it is they and not Crusoe that provides the main source of the force that carries Crusoe towards the shore: Crusoe endeavors to swim with the waves and to run as far as he can between surges of the sea. But it is clear that it is they and not him that provide the main source of motion. The mountain-like sea is only the first of several moments in which Crusoe's environment threatens him with a loss of bodily integrity.

The actual earthy ground makes Crusoe fear for his life in the famous episode in which he is shocked to see a single footprint on the shoreline. ${ }^{42}$ Seeing the print, Crusoe speculates that it has been made by the devil, or that it is his own, before finally coming to the conclusion, after he has compared the print to his own, that it has been made by a human interloper. Lynn Festa has discussed the footprint as one example of a number of objects in the first volume of Robinson Crusoe that do not conform to their expected shapes, including the "two large earthen ugly things, I cannot call them Jarrs," which Crusoe fashions to hold his grain $(R C, 91)$, the three "Hats, one Cap, and two Shoes that were not Fellows" $(R C, 91)$ belonging to his drowned fellow sailors he sees on the shore, and the awkward "pair of somethings, I scarce knew what to call them, like buskins, to flap over my legs" which Crusoe compares to "spatterdashes," $(R C, 89)$, footwear worn by equestrians to prevent their legs being splattered by flying mud. Festa reads the jars, the shoes, and the footprint as examples of objects failing to fit and hence spilling out of their own borders. ${ }^{43}$ All these objects are, however, either made directly out of the earth (as the jars and the footprint are) or

\footnotetext{
${ }^{42}$ It might be objected that sand is not really earth, but then Crusoe himself suggests that the line between sand and earth is a blurred one when he describes the wreck of the ship as having been driven onto "a bank of hard sand, or, rather earth" $(R C, 92)$.

${ }^{43}$ Lynn Festa, "Crusoe's Island of Misfit Things," The Eighteenth Century: Theory and Interpretation 52 (2011), 443-71. Wolfram Schmidgen writes similarly that "Crusoe's things do not fit existing forms" although he notes that Crusoe often seems unperturbed by this and treats "the misfit and the misshapen with affection." "The Metaphysics of Robinson Crusoe," ELH 83 (2016), 113.
} 
are proximate to it (like the various shoes of the first volume.) The jars, shoes, and footprint suggest not only isolatable objects that fail to hold a determinate shape but an enveloping earthy materiality that escapes the efforts of human beings to control it.

The footprint itself is not really an "object" in the same way that the jars and shoes are. It is, rather, a foot-shaped hole in the sandy beach and not a substantial thing in its own right, presenting a moment in which what would normally be seen as "ground" in the pictorial sense becomes "figure." ${ }^{44}$ It heralds another declivity that Crusoe sees much later: the "circle dug in the earth, like a cockpit, where I supposed the savage wretches had sat down to their human feastings upon the bodies of their fellow-creatures." Perhaps what is most disturbing about the footprint and the circle made in the context of the book as a whole is not simply the immediate threat they represent to Crusoe that he might be killed and eaten, but the way they register as holes opening up within the ground itself that produce the same sense of being sucked into his surrounding environment that he experiences when struggling in the sea. They present gaps in the earth that threaten to transform human "figure" into earthy "ground." Certainly, the footprint disturbs Crusoe's accustomed sense of the ground as a passive surface on which to walk. After encountering the footprint, Crusoe runs "Home to my Fortification, not feeling, as they say, the ground I went on." In his commentary on this passage, Michael Seidel remarks that Crusoe "moves so fast that his feet make no impression on the ground in contrast to the print that so frightens him." 45 This, however, seems to get things precisely the wrong way around. Crusoe's feet presumably do leave impressions on the ground and it is the ground that, from Crusoe's perspective, appears to make no

\footnotetext{
${ }^{44}$ On similar reversals of the figure/ground relationship in Charlotte Perkins Gilman's The Yellow Wallpaper, see Barbara Johnson, The Feminist Difference: Literature, Psychoanalysis, Race, and Gender (Cambridge, M.A.: Harvard University Press, 2000), chpt.1.

45 "Robinson Crusoe: Varieties of Fictional Experience," in The Cambridge Companion to Daniel Defoe, ed. John Richetti (Cambridge: Cambridge University Press, 2008), 197.
} 
impression on him. Crusoe is constantly confronted with earth that fails to conform to his will, failing even to act as a dependable surface for his feet to walk upon, and at other points threatening to swallow him whole.

The earth twice threatens to actually swallows Crusoe alive and return him to the ground from which he came. Soon after his arrival on the island, Crusoe begins work on an artificial cave to store his goods in the earthy and stony ground behind the main cave he calls home: "I began to work my Way into the Rock, and bringing all the Earth and Stones that I dug down out thro' my Tent, I laid 'em up within my Fence in the Nature of a Terras, that so it rais'd the Ground within about a Foot and a Half" $(R C, 102)$. As soon as Crusoe thinks that he has completed his work on the cave, however, "on a Sudden, (it seems I had made it too large) a great Quantity of Earth fell down from the Top and one Side, so much, that in short it frighted me, and not without reason too; for if I had been under it I had never wanted a Grave-Digger" $(R C, 112)$. Later on, the same scenario is played out on a larger scale, as Crusoe, working inside the entrance to his cave, is "terribly frighted with a most dreadful surprising Thing indeed; for all on a sudden I found the Earth come crumbling down from the Roof of my Cave, and from the Edge of the Hill over my Head." Fleeing his encampment, Defoe discovers the reason for the collapse:

I was no sooner stept down upon the firm ground, but I plainly saw it was a terrible earthquake, for the ground I stood on shook three times at about eight minutes distance, with three such shocks, as would have overturned the strongest building that could be supposed to have stood on the earth; and a great piece of the top of a rock, which stood about half a mile from me next the sea, fell down with such a terrible noise as I never heard in all my life: I perceived also the very sea was put into violent motion by it. $(R C, 116)$ 
The two near burials of Crusoe continue the motif of an earthy ground that seems imbued with an animate force. The ground startles Crusoe with footprints not his own, seems to drop out beneath him, nearly collapses around his body, and quakes and trembles beneath his feet.

The earth's vital energies are not, however, all threatening to Crusoe's existence.

Crusoe is, for example, more pleasantly surprised to see shoots of English corn emerging from the earth, apparently in the absence of his intention to sow any. One day when Crusoe is standing outside his tent, he writes "I was surpriz'd and perfectly astonish'd, when, after a little longer Time, I saw about ten or twelve Ears come out, which were perfect green Barley of the same kind as our European, nay, as our English barley" $(R C, 114-5)$. Crusoe first sees the appearance of the barley as a miraculous event, before he remembers having shaken out a bag that had contained chicken food outside his tent, at which point his amazement begins to abate. In retrospect, however, Crusoe comes to see the fact that he had inadvertently chosen the ideal spot for his first small crop to grow as so improbable as to be a sign of God's hand in the world. Simon Schaffer suggests that Crusoe's evolving understanding of the "miracle" of the barley loosely tracks the larger story of how the understandings of the earth's fertility moved "from the age of primitive superstition, when all events in the soil were attributed to the direct hand of God, through skeptical atheism, when naturalists reckoned they would explain all such events by the action of natural causes alone, to the mature rationality of providential deism." ${ }^{\prime 46}$ At the final stage of this sequence, the science of the earth becomes the ground of spiritual understanding and the evidence of God's providence is seen in natural powers of soil, sand, and stones.

Crusoe's own realization of God's role in the creation of the world occurs on the ground and is inspired by reflections on it. After his long sickness, Crusoe emerges from his

\footnotetext{
${ }^{46}$ Simon Schaffer "Earth's Fertility and Early Modern England," in Mikuláš Teich, Roy Porter, and Bo Gustafsson, Nature and Society in Historical Context (Cambridge: Cambridge University Press, 1997), 136.
} 
cave and, too weak to walk far, sits "upon the Ground, looking out upon the Sea" and asks himself "What is this Earth and Sea of which I have seen so much, whence it is produc'd, and what am I, and all the other Creatures, wild and tame, humane and brutal, whence are we?” The answer that "follow'd most naturally" is that "It is God that has made it all" $(R C, 125)$. This realization is made possible, in turn, by an earthy ground that continually forces itself on Crusoe's attention, presenting itself as something requiring explanation. In this way, the earth becomes a medium for a process of spiritual conversion that remains inextricably tied to the ground that produces it. In this context, Friday's twofold gesture of laying his head on the ground and setting Crusoe's foot above his head soon after his deliverance from the hands of the cannibals, an act that is read by Crusoe and many critics as a sign of his willing servitude, might also be read as a repetition of Crusoe's own earthy humiliations, an act by which Crusoe comes to stand to Friday in the same relation as God stands to Adam. ${ }^{47}$ Robinson Crusoe does, however, also insist on both Crusoe's and Friday's connection to the ground. Crusoe's apparent elevation above Friday in the episode in which Friday places Crusoe's foot on his head is neatly reversed in the odd episode in the Alps, at the end of the first book in the trilogy, in which the spatial elevation of Crusoe above Friday is overturned when Friday tricks a bear into following him up a tree. As Crusoe and the rest of the party watch from below, Friday draws the bear down to the ground again, and shoots the bear at the point on which it is about to set foot on the ground. As well as converting Friday into teacher and Crusoe into tutee, this otherwise puzzling episode might be read as an object lesson on the perils of disconnecting oneself from the earth: a recurrent concern throughout the trilogy as a whole. The Crusoe books insist on the earthiness of Crusoe, Friday, and all human beings, showing them to stand to God in the same relationship that the two earthen jars stand to

${ }^{47}$ George Boulukos, for example, sees Friday as "eagerly offering himself as a slave." See The Grateful Slave: The Emergence of Race in Eighteenth-Century British and American Culture (Cambridge: Cambridge University Press, 2008), 2. 
Crusoe. Crusoe compares himself and his fellow human beings to earthenware in the course of discussing the problem of why God appears to have arbitrarily revealed his word only to some peoples and to have hidden it from others, writing "as we are all the Clay in the Hand of the Potter, no Vessel could say to him, Why hast thou form'd me thus" $(R C, 212)$. Both Crusoe and Friday alike are earthy objects in God's hands, entering into a process of spiritual conversion even as they themselves perform agricultural conversions on an earth that is already in motion.

Even in the Serious Reflections during the Life and Surprising Adventures of Robinson Crusoe (1720), in which Crusoe outlines a model of an "invisible world" that influences the material one largely through immaterial voices and dreams, Crusoe is still bound metaphorically to the earth as the only means of apprehending this world. He describes humankind as tenants laboring under the divine maker, for whom,

the Peace of the Creation is preserved, the Climates made habitable, the Creatures subjected and made nourishing, all vegetative Life made medicinal; so that indeed the whole Creation seems to be entail'd upon him as an Inheritance, and given to him for a Possession, subjected to his Authority, and governed by him, as Viceroy to the King of all the Earth; the Management of it is given to him as Tenant to the great Proprietor, who is Lord of the Mannor, or Landlord of the Soil. And it can not be conceiv'd, without great Inconsistency of Thought, that this World is left entirely to Man's Conduct without the supervising Influence and the secret Direction of the Creator. ${ }^{48}$ Just as earth allows the idea of a spiritual world to be produced so too does it create the idea of a soul to be nurtured. Virtues and vices are described as metaphorical plants in the Serious Reflections: honesty "is a little tender Plant" $(S R, 75)$ and cunning is an "ugly weed" $(S R, 76)$.

${ }^{48}$ Daniel Defoe, Serious Reflections during the Life and Strange Surprising Adventures of Robinson Crusoe, ed. G.A. Starr (London: Pickering \& Chatto, 2008), 182. This and all subsequent references are to this edition, designated as $S R$ in the text. 
Whilst Crusoe connects spiritual reflections to earthy materials in the Serious Reflections, he also reminds readers that too much abstract speculation on spiritual subjects can distract from earthy matters at hand. Crusoe tells an anecdote early on in the Serious Reflections of a "poor but good man" who, "though he was a labourer, was a man of sense and religion, who, being hard at work with some other men removing a great quantity of earth to raise a bank against the side of a pond, was one day so out of himself, and wrapt up in a perfect application of his mind to a very serious subject, that the poor man drove himself and his wheelbarrow into the pond, and could not recover himself till help came to him" $(S R, 65)$. The anecdote works as a fable showing the dangers of being so wrapped up in the contemplation of the spiritual world that one neglects the earthy world of the here and now. The Serious Reflections may seem like the interloper in the Crusoe trilogy in that it does not continue the narrative developed in the first two books but reads instead as a series of essays. But the third book shares the first two books' concern for coordinating the spiritual and material worlds, defining them as separate realms that are nevertheless joined in the act of laboring on the earth.

In the second book in the series, the Farther Adventures of Robinson Crusoe (1719), problems befall the island colony that Crusoe founded in the Strange and Surprising Adventures as soon as the connection between spiritual and earthy labor is broken. The colony becomes unstable when three of the former English mutineers, including an unreformed Will Atkins, refuse to work the ground. They approach the two other Englishmen on the island, whom Crusoe calls "honest" so to distinguish them from the three reprobates, and tell them "That they came on Shore without Leave, and they should not Plant or Build upon the Island, it was none of their Ground." 49 One of the men goes on to offer one of two examples identified by the Oxford English Dictionary of the term "ground-landlord,"

${ }^{49}$ Daniel Defoe, The Farther Adventures of Robinson Crusoe, ed. W. R Owens (London, Pickering \& Chatto, 2008), 35s. All subsequent references are to this edition, designated as $F A$ in the text. 
meaning "the owner of the land which is leased for building on," telling the three men "If they were Ground-Landlords, he hoped, if they built Tenements upon their Land" that the Englishmen would "grant them a long Lease." The three "wicked" Englishmen then tear apart the "honest" Englishmen's habitations, scatter their possessions on the ground, pull up the trees they have planted, and destroy some of the fencing the men are using "to secure their Cattle and their Corn" $(F A, 36)$. The disorder the men create within Crusoe's colony stems from their claim that they "could not work, and would not work" $(F A, 50)$. Rather than toiling on the ground, the three reprobates seek to interpose other people between themselves and the island's soil, first the two Englishmen they seek to turn into tenants and then the three slaves they later acquire and put to work. Crusoe seeks to distinguish his own treatment of Friday, whom he had himself set to work on the island's earth, from those of the "wicked" Englishmen, one of whom seriously wounds a slave during a dispute over an uncompleted task. Crusoe goes as far as to deny that Friday is in fact a being that comes between him and the ground, describing him rather as an extension of his own body: "as true to me as the very Flesh upon my Bones" $(F A, 60)$. The Crusoe books as a whole move asymptotically towards the limit at which master would meld with servant and laborer with ground. The effort to foreground an ideal closeness of labourer with the material on which he labours is belied by the fact that Crusoe's own fortune is in fact made not by any work that he or Friday perform on the island but rather by the slaves laboring in his absence on his plantation in South America. The books nevertheless attempt to ground the large-scale project of colonization and the far-flung chains that separate consumers from producers with the Crusoean ideal of essentially solitary laborer proving his virtue by laboring on the earth.

The second half of the Farther Adventures of Robinson Crusoe, in which Crusoe leaves the island for the Far East, endeavors to incorporate even trade with China into its vision of spiritual redemption achieved through labor on the earth. The attention to the link 
between labor and the earth helps smooth over what Robert Markley regards as a radical break that opens up in the second half of the Farther Adventures, in which "the colonialist parable of Robinson Crusoe is abandoned" in favor of "visions of an infinitely profitable trade to the Far East and the South Seas." ${ }^{50}$ But there is an important source of continuity between Crusoe's experiences on the island and his experiences in China, supplied by the earthenware that is created in both locations. As Lydia Liu observes, Crusoe, in his experiments with making earthenware pots, happens upon a method of making red porcelain, or at least something very close to it, when he discovers a red tile in the ashes of the fire he has used to cook meat, and is subsequently inspired to try to create a whole pot made from the same earthenware he has inadvertently made. ${ }^{51}$ The accidental creation of porcelain-like earthenware serves to suggest that the art of creating this desirable commodity is a simple one well within the reach of Europeans, if they only had the right kind of earth to make it with.

In his travels in China in the Farther Adventures, Crusoe recounts a visit to a "ChinaWarehouse" that makes porcelain products, Soon after his departure from Beijing, Crusoe recounts how its "Earthmakers, that is to say, People that tamper'd the Earth for the China ware" showed him a house that he is told is made entirely out of porcelain, but which he writes is in fact only a wooden house "plaister'd with the Earth that makes China Ware" (FA, 181). The purpose of this passage is not simply to humble Chinese architectural achievements - and this is one of the milder barbs Crusoe throws at China and the Chinese in the second half of the Farther Adventures - it is also to assert the sameness of earth across the planet as a whole. The distinction of the porcelain craved by English consumers is simply that it is made out of the same "Earth that makes China ware." Much as the word "earth" is

\footnotetext{
${ }^{50}$ Robert Markey, "The Farther Adventures of Robinson Crusoe," in A Companion to the Eighteenth-Century English Novel and Culture, ed. Paula B. Backscheider and Catherine Ingrassia (London: Wiley-Blackwell, 2009), 28.

${ }^{51}$ Lydia H. Liu, "Robinson Crusoe's Earthenware Pot," Critical Inquiry 25 (1999), 739-41.
} 
capable of signifying a handful of soil as well as the whole world, the word "china" is capable of signifying a small piece of material as well as an immense country. As Liu writes of Crusoe's discovery of the true construction of the china house, "Inasmuch as Crusoe's act of unmasking turns china into a synecdoche of China (a pun made easy by early modern typography), the violence is directed at both." 52 The semantic link between the china/China and earth/Earth helps enable the mental fiction that Crusoe can hold the country and the planet in his head just as easily as he can hold a piece of china and a portion of soil in his hand.

The imaginative levelling of earth and the commodities that are made from it across the planet as a whole helps prepare for the moment when, having left China on his journey from Asia to Europe and reached the plains of Siberia, Crusoe remarks "We were now launch'd into the greatest Piece of solid Earth, if I understand any thing of the Surface of the Globe, that is to be found in any Part of the Earth" and goes on to give estimates for the number of miles standing between him and the seas to the east, west, north, and south. The moment allows Crusoe to claim imaginatively the earth stretching from China to Europe, including what he calls "the Earth that makes China Ware." This evocation of a geographical sublime anticipates the sixth essay of the Serious Reflections, "Of the Proportion between the Christian and Pagan World," which Crusoe begins by dividing up the earth's surface into parts and estimating the total area of the world inhabited by Christian believers, as well as the last essay "A Vision of the Angelick World," in which Crusoe dreams of leaving "the Vestiges of the Earth" and sets "my firm Foot upon the verge of the Infinite" $(S R, 237)$.

\footnotetext{
52 Ibid., 752. For an extended account of how Defoe's later fiction Captain Singleton "attributes to its English castaways the commercial ingenuity and success that historically were enjoyed by Chinese manufacturers selling to European markets" (109) see Eugenia Zuroski Jenkins, A Taste for China: English Subjectivity and the Prehistory of Orientalism (Oxford: Oxford University Press, 2013), chpt. 3.
} 
The passage from the porcelain workshop to the continental center is an example of how the Crusoe trilogy in general depends on a movement from small pieces of earth to the earth as a whole: from Crusoe's plots of land on his island to the plantations across the Americas, and from the chinaware Crusoe inspects in the workshop to the Eurasian continent. Although the books show that solitary labor on a single island cannot easily be taken as a model for the project of planting the New World and that the global trade in earthenware is not one that can be controlled by Christian Europe, the Crusoe trilogy nevertheless works to produce a sense of human interpenetration with the earth and its materials at both the very small and the very large scales. A decade before writing the Crusoe books, Defoe had in the Review described the intertwined processes of colonization and trade as forces capable of reshaping the earth's surface. As we saw earlier, in his response to Burnet's Theory of the Earth in the General History of Trade, Defoe argued that the dislocation of the earth had created the very possibility of commerce. In the Review, Defoe reflects on how trade, in turn, dislocates the earth even further, observing that "Trade carries the very Soil away, and transposes the World in Parts, removing Mountains, and carrying them over the Sea into other Countries." 53 In both the cases, for Defoe at least, nature is not so much ruined as revitalized by these cataclysms. Postdiluvian human beings rival the flood as a force capable of shaping the earth into new and strange forms, working changes on the earth more drastic than any landslide or earthquake could wreak. The Crusoe trilogy works out this vision from the perspective of one earth-wandering human being, in which Britons emerge as key players in colonial and commercial projects capable of reshaping the very surface of the globe.

\footnotetext{
${ }^{53}$ Daniel Defoe, Defoe 's Review, ed. Arthur Wellesley Secord, 22 vols. (New York: Published for the Facsimile Text Society by Columbia University Press, 1938), vol.3, no.1, 7. Qtd. in Bruce McLeod, The Geography of Empire in English Literature, 1580-1745 (Cambridge: Cambridge University Press, 1999), 243.
} 
Over the course of the Strange Surprising Adventures and the Farther Adventures, Crusoe comes to realize the vitality of the earth and the earthiness of his body. His defamiliarized perception of the earth makes possible, in turn, the conversion of his own soul, a conversion prepared for and confirmed by his labors on the ground. Spiritual redemption and commercial prosperity, whether achieved through the planting of colonies or the pursuit of trade, are both predicated on an awareness of human beings' origin in the earth and ultimate fate to return to it. The Crusoe trilogy as a whole understands human beings as outgrowths of the earth's own animate forces, working alongside the powerful and often destructive processes of an earth that was already in motion before Crusoe came to exist and will continue to move once he has departed from its surface. One implication of my reading of the Crusoe trilogy is that to recognize the human beings' entwinement with the earth is not necessarily to see the need to tread lightly on it. If Crusoe shatters and shifts the face of the earth, then he is only acting as an extension of the earth's own violent energies. In this essay I have tried to show that it is only by altering our perspective slightly, and directing our gaze to the ground, that we realize the extent to which the true protagonist of the Crusoe trilogy is not Crusoe at all, but the earth turning ceaselessly under his feet. 